\title{
Improving the Performance of Small and Medium-Sized Tourism Enterprises (SMTEs) in Primorsky Region: The Role of Strategic Entrepreneurship
}

\author{
Muhanad Hasan Agha*, Elena Gafforova \\ Far Eastern Federal University, Vladivostok, Russia
}

\author{
Информация о статье \\ Поступила в редакцию: \\ 10.03.2020 \\ Принята \\ к опубликованию: \\ 08.04.2020
}

УДК $379.85 ; 65.012$

JEL L26; Z32

Keywords

Primorsky region, Tourism industry, Management methods, Strategic entrepreneurship, Small and medium-sized businesses, SMTEs, Company's performance

\begin{abstract}
With the increasing role played by tourism worldwide, Russia is turning to use tourism as an effective tool for overall development. Primorsky region is one of the leading tourist destinations in the Russian Far East where several Small and Medium-sized Tourism Enterprises (SMTEs) are operating to offer a variety of products, all of which constitute a tourism experience. Thus, there is a growing interest in the performance and management methods of such companies. Through the analysis of literature, this paper discusses tourism trends in Primorsky region and studies SMTEs working in there through exploring their characteristics and the challenges they are facing. The paper also investigates Strategic Entrepreneurship (SE) as an appropriate management method for managing SMTEs in Primorsky region. The study finds that both components of SE positively affect the performance of SMTEs. Consequently, the application of SE in SMTEs in Primorsky region might enable managers and owners of SMTEs to overcome the various challenges and shortcomings experienced by these companies and to exploit their resources in a way that helps them achieve the best possible performance without waiting for large investments in the region.
\end{abstract}

\section{Introduction}

Tourism, in the 21st century, plays a main role in the global economy. Since countries more and more tend to open up their borders in order to participate in the wave of global integration, the development of tourism industry has become a source of substantial foreign exchange revenues and a contributor to job creation for numerous economies [1].

In Russia today, the tourism industry receives great attention from both the government and

\footnotetext{
* Автор для связи: agha.muhanad@gmail.com
}

DOI: https://dx.doi.org/10.24866/2311-2271/2019-4/91-102 
investors. The incoming tourist flow is growing year by year, mainly due to the depreciation of the ruble, which makes the prices of tourist services in the Russian market quite attractive for foreign guests. [2].

According to the World Travel \& Tourism Council (WTTC), in 2017, travel and tourism in Russia directly contributed $1,135.6$ billion rubles, $1.2 \%$ of total GDP and supported 854.5 thousand jobs, $1.2 \%$ of total employment. Taking its wider indirect and induced impacts into account, the sector contributed 4,434.5 billion rubles, $4.8 \%$ of the Russian GDP and supported 3,256.5 thousand jobs (4.5\% of total employment) in 2017 [3].

One of the important regions of the Russian Far East is Primorsky region, which is featured by its convenient geopolitical location and its unique recreational resources. In this part of the planet, tourist flows are generated mainly from the AsiaPacific region. There are 400 million potential tourists an hour away from the capital of the region, Vladivostok, which creates promising opportunities for tourism [4].

The development of tourism market in Primorsky region differs from global trends. So, it is necessary to study it in order to find tools that might increase its level of competitiveness and ensure its sustainable growth [2]. This could be reflected on the performance of the tourism companies operating in the region, which by combining their individual products, the overall tourism product is produced [5].

Having performed a literature review, the paper studies the tourism trends in Primorsky region and explores the nature of tourism companies operating in the region. The research also looks at Strategic Entrepreneurship (SE) as an appropriate management method capable of enhancing the performance of tourism companies. The study aims to theoretically justify the suitability of SE as a management method for tourism companies in Primorsky region.

\section{Research Methodology}

This is a conceptual article wholly based on literature. The study focuses on discovering theoretical reasons that turn SE into an effective management method in improving the performance of tourism companies in Primorsky region.

The literature review starts off with the search for SE concepts and models, and for the trends of tourism and the characteristics of tourism companies in Primorsky region and the factors that affect their performance. The most famous international data bases (Scopus, Web of Science, ScienceDirect and Emerald) side by side with different Russian articles were recognised, in addition to the latest reports about tourism in Russia and Primorsky region. The publications on SE and its components (strategic management and entrepreneurship) by the most renowned authors, such as Ireland, Hitt and Sirmon, Klein, Barney and Fossare, Ritala, Shane and Venkataramanare, are discussed and the most prominent scholars studying tourism performance, such as Zach and Racherla, Wang and Krakover are distinguished. Also, the most recent publications on tourism industry and tourism companies in the Primorsky region by well-cited authors such as Pakhomova and Namestnikova, Titova and Syaoyuy are taken into account.

The literature review shows that the components of SE still undetermined which give liberty for scholars to be creative in how they conceptualize and identify SE behaviour using well-established methods in both strategic management and entrepreneurship in a manner that fits the studied environment as Klein et al. [2012] pointed out. While for the performance of tourism companies in Primorsky region, the review shows that most companies are Small and Medium-sized Tourism 
Enterprises (SMTEs) which should work to improve their performance independently of big investments in the region, as in Titova and Syaoyuy [2019].

Shirokova, Vega and Sokolova [2013] indicated that SE focuses on enhancing companies' performance. Since different factors exert influence on the performance of SMTEs in Primorsky region, there arises the question whether SE as a management method is compatible with the characteristics of SMTEs operating in the region and the factors affecting their performance. It is the focus of the present study.

The literature review analyses, firstly, the trends of tourism in Primorsky region and the characteristics of SMTEs operating there; secondly, the factors that influence their performance, and thirdly, the main SE concepts.

\section{Tourism Trends in Primorsky Region}

Primorsky region has diverse natural, cultural and historical potentials and resources. Many of these resources have not been exploited yet, either by the local tourism authorities or by the tourism companies operating in the region. Taking advantage of this potentials would allow developing different types of tourism and contribute to the development of the tourism sector in Primorsky region, which, in turn, would have a positive influence on the economy of the region.

One of the most common tourism types in Primorsky region is coastal ecotourism. The most popular hiking trails are mountain climbing, including Pidan Mountain, which rises 1,332 meters above the Sea of Japan [6]. Tourists can also find extreme activities in Primorsky region such as diving, windsurfing, parachuting, paragliding, skiing, snowboarding, equestrian sports and caving. Fishing, in turn, is very popular in Primorsky region, which is leading to advanced fishing tourism [7].

Regarding the development of tourist infrastructure and the concentration of cultural and historical sites, Primorsky region ranks first in the Far Eastern Federal District [6]. Also, in the region, there is a modern infrastructure for holding conferences with a number of participants of 1,000 or more side by side with experience in organizing such events and ability to provide services to host business travellers and official delegations of any level, even heads of states [7].

Furthermore, the tourism sector in Primorsky region has powerful potential resources of tourists. Direct flights link Vladivostok with several cities in Japan, Republic of Korea, China, North Korea, Thailand, and Vietnam. Also, there are several ports in Primorsky region ready to receive foreign cruise ships sailing to the region [8]. Also, across the entire Primorsky region, the Trans-Siberian Railway passes with additional paths to the country's borders and to the seacoast. In this regard, the region also plays an important economic role considering that Primorsky region is a path for the foreigner and Russian transit passengers providing a full range of tourism services for them [9].

Primorsky region is one of the most promising regions for the development of domestic and incoming tourism. In 2018, the tourist flow to the Primorsky region increased by 530.8 thousand tourists (13.1\% compared to 2017) and reached 4583.7 thousand tourists, of which 651.8 thousand were foreigners (25.8\% higher than 2017) [10]. An important reason for the increasing flow of Russian citizens to the Primorsky region is the devaluation of the ruble which has caused Russian tourists to focus more on domestic tourism.

Considering incoming tourism, the geopolitical location of the region strengths its orientations towards Asia-Pacific countries. China is the primary exporting coun- 
try of tourists to the Primorsky region with an influx of 365.5 thousand tourists in 2018. However, the existing infrastructure of cross-border checkpoints of cars and trains limits the possibility of increasing the incoming tourist flow from China. Taking into account the flow growth dynamics among the main partners of the Primorsky region in 2018, Republic of Korea headed the top ranking that 222 thousand tourists visited the region over the year (an increase of 132.7\%) while the second place was occupied by Japan [10].

This trend of tourism in Primorsky region can be evaluated extremely positively. The increase in the number of foreign tourists has a direct positive impact on the economy of the region. The economic impact of tourism development is evident. For each ruble invested, the business receives 3 to 5 rubles of profits. Also, each job place in tourism industry creates up to 5 jobs in related industries [11]. According to WTTC, tourism leads to the development of 53 sectors of the economy, which gives a great synergistic effect, almost instantly [3].

In 2018, revenues from tourism activities (tourism, hotels, restaurants, etc.) in Primorsky region to the Russian budget system increased by $28 \%$ compared with 2017 and reached about 1,449.2 million rubles. Also, the amount of paid services in collective and individual accommodation facilities, including micro-enterprises, small enterprises and individual entrepreneurs raised into 18.6 billion rubles in 2018, while in 2017 it amounted to 6.5 billion rubles [10].

As for macroeconomic indicators, in 2018, tourism sector in the Primorsky region directly contributed 23.0 billion rubles, $2.9 \%$ of Gross Regional Product (GRP) and supported 39.9 thousand jobs. Taking its wider indirect and induced impacts into account, the sector contributed 51.9 billion rubles, $6.5 \%$ of GRP and supported 59.56 thousand employees (5.9\% of the total employment in Primorsky region's economy) in 2018 [10].

However, despite the rapid development, the tourism sector in Primorsky region is faced by a number of problems. Among them are the following [2]: Low level of social infrastructure development; lack of a reliable operational information base of tourism resources, facilities, services, trusted forms and methods of tourism statistics and a system for collecting marketing information which impedes the full promotion of a regional tourist product; a limited number of large-scale events at regional and international levels; bad roads quality; lack of specialists at various levels, whether working in accommodation facilities, or working in travel agencies; high prices for air travel and tourist accommodation facilities, which reduces the competitiveness of the regional tourism product in the international tourist markets of the Asia-Pacific region.

The main feature of the Russian tourism market is that most of its participants are small enterprises whose resources are insufficient to define strategic goals and find ways to increase their competitiveness [12]. In 2018, the number of SMTEs in Primorsky region amounted to 1,487 companies [10]. Studies show that the main problems that impede the development of SMTEs in Russia include: inconsistent SMTEs support system: administrative barriers at all levels (federal, regional and municipal); limited access to financial resources at a low-interest rate, in addition to a high tax burden; weak regulatory, technical and media basis for supporting SMTEs [11].

Thus, in order to increase the competitiveness of SMTEs operating in Primorsky region, without attracting large investment to develop the region [12], and 
also to improve the performance of these companies, SMTEs should work on exploiting the great tourism opportunities and potentials existing in the region.

\section{Performance of SMTEs in Primorsky Region}

In its quest to achieve superior performance, SMTEs should adopt appropriate strategies to enable them to overcome different challenges.

Contemporary business theory discusses that the superiority in performance resulting, in part, from the synergy of value-adding relationships developed between individual organizations [13].

The Resource-Based View (RBV) and its complement, the Dynamic Capabilities-Based View (DCBV), as a part of strategic management theory, argue that firms attempt to obtain and sustain a competitive advantage through the strategic use of resources. This framework proposes that firm-specific idiosyncrasies in the accumulation and leverage of unique and durable resources are the source of sustainable competitive advantage which leads, as a result, for more profits [5].

However, important resources (such as money, skills, etc.) are often scarce and not available in SMTEs. SMTEs, therefore, enter into cooperation, even with their competitors, to take advantage of complementary assets and capabilities. It has been well confirmed that inter-organizational cooperation helps tourism organizations overcome individual resource shortages and, thus, remain competitive [14].

Also, a destination, especially from the viewpoint of visitors, can be interpreted as a series of interrelated activities and attractions that have to work in unison to create a satisfying and wholesome experience. In this sense, although a destination consists of a lot of independent organizations, visitors tend to see them as a whole [15].

Therefore, SMTEs should be concerned about developing the tourist destination, and all SMTEs should work with each other by focusing on the common benefits of the destination where they are operating and not only on their opportunistic goals [16]. Consequently, the amalgam of products and services provided by all SMTEs at the destination level should aim to maximise the satisfaction of consumers' needs and wants. In this sense, SMTEs need to cooperate at the destination level in order to increase their total competitiveness as a destination (or as the total tourism product) against substitute tourism and leisure products or factors which reduce their profitability or market share [5].

The strategic management response by SMTEs, in such case, is to cooperate in some areas such as destination planning and development, and also to combine their limited marketing resources in order to attract tourists [17]. Thus, in tourism destinations, often SMTEs both compete and cooperate at the same time.

In neoclassical economics competitive and cooperative strategies are independent and oppositional - "competition and cooperation do not mix" [18, p. 71]. However, other streams of research, notably that of behavioural and game theorists, argue that in practice these strategies are used by companies at the same time. One of the concepts, namely "coopetition", particularly focuses on the simultaneous combination of cooperation and competition. In this study, coopetition is simply defined to be simultaneous cooperation and competition between firms [19] regardless in what part of the value chain, supply chain or supply network these two will emerge [20]. Through a coopetition strategy, companies may cooperate in achieving mutual goals with their partner and at the same time compete with each other in gaining individual benefits [17]. 
Coopetition is consistent with RBV, considering that "bunching together creates complementarities that develop the market even if there's sometimes more competition in dividing it up" [21, p. 34].

As a result, we can say that coopetition is a key strategy for SMTEs when it comes to leveraging scarce resources, and fulfilling tourists' need for holistic and individually meaningful experiences.

In a related context, a dynamic capability is the destination/firm ability to integrate, build and continuously reshape tourism competencies to address rapidly changing environments, exploiting/exploring local resources such as landscape, heritage, infrastructure and so on. Further, when possible, weaknesses should be reduced and can sometimes even be turned into strengths, just as external threats can be considered potential opportunities to explore and exploit. This is possible through a creative exploration of local assets coupled with a governed renewal of tourism competencies [22].

Entrepreneurship and the entrepreneurial process is usually described with terms such as "creativity", "innovation", "exploitation of opportunity", and "financial motivation and growth" [23].

Entrepreneurship as a research field involves multiple definitions, perspectives and disciplines, and the task of defining mainstream entrepreneurship research is not straightforward. The opportunity-based perspective is one of the most common views of entrepreneurship. This view places the pursuit of an opportunity at the core and defines entrepreneurship as the discovery and exploitation of business opportunities [24].

Entrepreneurs often see what others do not. In other words, they usually recognize the existing opportunities before others can identify them. They do so because they are alert to such opportunities. McGrath and MacMillan [2000] point out that people with keen entrepreneurial alertness demonstrate an entrepreneurial mindset [25].

Importantly, entrepreneurs act to exploit and appropriate value from the opportunities identified. This may take the form of investing in real options to have the right to act on an opportunity later. Or, more likely, entrepreneurs create innovations. Inventors are rarely successful entrepreneurs because invention and successful commercialization require quite different capabilities. Entrepreneurs identify inventions and commercialize them, thereby creating innovations in the marketplace [26].

Thus, it can be said that both entrepreneurial mindset and innovation are essential dimensions of the entrepreneurship process in the company.

An entrepreneurial mindset is defined as a focus on creativity and renewal, capturing scanning efforts to seek out, identify and develop opportunities for new business [27]

The innovating component represents the means by which creativity is realised and applied in the firm. The act of innovating entrepreneurially can assist firms to exploit entrepreneurial opportunities in radical, discontinuous and disruptive ways that ultimately shift the basis of competition in the industry towards the firm [28].

Thus, strategic management deals with how companies achieve and maintain competitive advantage [27]. It requires a focus on competition through strategy, positioning, benchmarking, and the development of rare, valuable, and imperfectly imitable resources and capabilities [29]. Conversely, entrepreneurship is a process of "creative destruction" where innovation deconstructs existing structures to discover and 
exploit profitable opportunities, allowing the deployment of resources and capabilities in new and unique ways as a means of wealth development [24].

The combination of strategic management and entrepreneurship has long been recognized as an important pathway for the performance and growth of the companies [5].

Here, SE appears as a framework that combines these two areas. SE is a superior management method which is compatible with the complex structure of SMTEs, so that its use by managers of this type of company in Primorsky region could lead to superior performance in both the company and the destination.

\section{SE as a Management Model for Managing SMTEs in Primorsky Region}

SE was originally described as a successful integration between strategic management and entrepreneurship - taking entrepreneurial actions with strategic perspective or taking strategic action with an entrepreneurial mindset [30]. More specifically, SE is recognized as the efforts of a firm to "combine effective opportunityseeking behaviour (i.e., entrepreneurship) with effective advantage-seeking behaviour (i.e., strategic management)" [27].

It is difficult for any firm to grow and remain competitive while focusing on only one discipline [27]. Robert Burgelman indicates the need for both diversity and order, suggesting entrepreneurial activity provides such diversity; strategy provides the necessary order [31]. Venkataraman and Sarasvathy argue that entrepreneurship and strategy are conceptually inseparable: "two sides of the same coin" [32, p. 651] highlighting the interdependent or complementary nature of the two concepts.

The focus of scientific efforts on either strategy or entrepreneurship gives an incomplete picture of a modern company. The reality of organizational behaviour is much more complicated and interesting since managers trying to manage their organizations in ways that create wealth must conflict with the challenges posed by both strategy and entrepreneurship. Thus, the use of either strategy or entrepreneurship, excluding the other, could reinforce the possibility of the ineffectiveness or even the failure of the company [33]. On the opposite side, scholars indicated that the expected results of SE include improved competitive advantages and, in the longer term, wealth creation [34].

Since SE is an overall perspective that encompasses broad aspects of strategic management and entrepreneurship, it is necessary to define the concepts adopted from each area. Klein et al. [2012] indicate that "SE scholars use constructs, theories, and methods well-established in the two fields" [35, p. 3].

In this context, forward we will discuss the influence of utilising each of entrepreneurial mindset and innovation on one side, and coopetition on the other on the performance of SMTEs.

\section{Discussion}

The company that has developed an entrepreneurial culture will constantly be innovating, improving and finding new ways to increase profits and grow. This is especially relevant for SMTEs, which, due to limited resources, must be constantly seeking new opportunities and be innovation-oriented to survive and grow [36].

Scholars find evidence that companies with entrepreneurial attitudes achieve better performance. This is the way to prove the higher profitability of companies with stronger entrepreneurial potential than conventional ones. Additionally, more 
rapid growth was noted as an inherent characteristic in companies with internal entrepreneurial initiatives [37].

On the other hand, the entrepreneurial component leads to improvement in different organizational processes, which, in turn, influences the economic performance of companies. For example, the rate of innovation (product, process, administrative) relies on the level of elements of corporate entrepreneurship [38]. Numerous sources refer that company could enhance performance by developing new ideas for products and processes [39]. Shirokova et al. argue that entrepreneurial ideas are becoming the basis for the development of new activities in autonomous organizational units through updating the portfolio of products/services of firms and expansion into new markets which leads to improved company performance, usually expressed in increasing profits and company growth [40].

Moreover, in order to improve performance, SMTEs enter into different coopetitive alliances. Aside from the motives for joining the alliance, a coopetitive alliance has several effects. Coopetition may be beneficial in terms of both innovation performance and market performance [41]

Coopetition strategies have been emphasized as the main triggers for innovations as they allow firms to develop new products, and innovative business models, learn from partners and share knowledge, and protect innovations from imitation [42]. Accordingly, coopetition potentially offers competitive advantages that derive from the firm's ability to develop products or services that the same firm on its own could never develop or would take too long to do so [43].

Regarding the effect of coopetition on the overall firm performance, we can notice that engaging in coopetitive relations can be very risky; indeed, competitors can be the riskiest partners. For instance, there is a high risk of opportunism and undesired knowledge spillovers between coopetitors [44]. However, at the same time, coopetition is an efficient risk-sharing and risk-reduction strategy. Thus, coopeting parties can have access to additional resources [19], share costs and risks of failure of innovative projects [42]. This, in turn, is reflected positively on the performance of SMTEs.

On the other hand, SMTEs collaborate with their competitors through the sharing of resources and capabilities to perform better than if they operated on an individualistic level [44]. So, coopetition is intended to help SMTEs to improve their performance in ways that would not be possible without competitors' resources and capabilities [20]. Additionally, Crick [2018] found that if a group of competing brands were to collaborate and run promotional events (like trade shows), customers would be more interested, which could potentially improve the sales of all the organizations involved [45].

Additionally, in the tourism context, coopetition involves two different logics of interaction. On the one hand, there is hostility due to conflicting interests of getting a bigger piece of the business once the visitors are in the destination; on the other hand, it is necessary to pool resources and develop mutual commitment to achieve the common goal of attracting the visitors to the destination. Koza and Lewin [1998] try to understand the issue from a market perspective. They believe that the proximity of an activity to its customer seems to be of importance for the division between cooperative and competitive interactions [46]. That is, the cooperative or competitive relationship are divided due to the closeness of an activity to the customer, in that firms compete in activities close to the customer and cooperate in activities far from the customers. Bengtsson and Kock [2000] argue that coopetition is, in fact, the most 
mutually advantageous relationship for competitors [20]. Thus, coopetition could improve the performance of all firms engaged in such activities.

\section{Conclusion}

In this paper, through the analysis of scientific publications, we studied tourism trends in Primorsky region and SMTEs operating there due to the fact that this type of companies represents the majority of companies in the region, and also because their individual products shape the overall tourism product of the region. We focused on the different factors that affect the performance of SMTEs and the ways to improve it. Then we touched upon SE as a promising management method that enables managers and owners of SMTEs to overcome various challenges and shortcomings and exploit their resources in a way that achieves the superior performance.

\section{Список источников / References}

1. Giap T.K., Gopalan S., Ye Y. Drivers of growth in the travel and tourism industry in Malaysia: A Geweke causality analysis. Economies, 2016, vol. 4, no. 3, pp. 1-15.

2. Гриванов Р.И., Шматова Д.Д. Туристский кластер в экономике Приморского края: проблемы реализации стратегии развития и перспектива для региона. Региональная экономика: теория и практика, 2018, т. 16, №3, сс. 579-572. [Grivanov R.I., Shmatova D.D. Turistskiy klaster v ekonomike Primorskogo kraya: problemy realizatsii strategii razvitiya i perspektiva dlya regiona [Tourism cluster in the economy of the Primorsky region: the problems of implementing development strategy and perspective for the region]. Regionalnaya ekonomika: teoriya i praktika, 2018, vol. 16, no. 3, pp. 579-572.]

3. WTTC. Travel \& Tourism Economic Impact 2018 Russian Federation. London: WTTC, 2018.

4. Балдина Ю.В., Петрук Г.В., Лебединская Ю.С. Государственно-частное предпринимательство как инструмент динамичного функционирования туристского кластера в условиях территорий опережающего развития (на примере Приморского края РФ). Экономические и соииальные перемены: факты, тенденции, прогноз, 2017, т. 10, №1, cc. 200-215. [Baldina Yu.V., Petruk G.V., Lebedinskaya Yu.S. Gosudarstvennochastnoye predprinimatelstvo kak instrument dinamichnogo funktsionirovaniya turistskogo klastera $\mathrm{v}$ usloviyakh territoriy operezhayushchego razvitiya (na primere Primorskogo kraya RF) [Public and private sector entrepreneurship as a tool of dynamic functioning of tourism cluster at the territories of outstripping development (case study of Primorsky krai, Russian Federation)]. Ekonomicheskiye i sotsialnyye peremeny: fakty, tendentsii, prognoz, 2017, vol. 10, no. 1, pp. 200-215.]

5. Hasan Agha M., Gafforova E. B. Strategic entrepreneurship: A management method for improving the performance of small and medium-sized tourism enterprises (SMTEs). Upravlenets - The Manager, 2019, vol. 10, no. 3, pp. 25-35.

6. Мартышенко Н.С. Формирование концепции экологического туризма на территории Приморского края. Вестник Удмуртского университета. Серия «Экономика и право», 2013, №4, сс. 59-65. [Martyshenko N.S. Formirovaniye kontseptsii ekologicheskogo turizma na territorii Primorskogo kraya [Formation the concept of ecological tourism in the territory of the Primorsk region]. Vestnik Udmurtskogo universiteta. Seriya «Ekonomika i pravo», 2013, no. 4, pp. 59-65.]

7. Латкин А.П., Веркеенко В.В., Белоглазова В.А. Туристско-рекреационный кластер «Приморское кольцо»-приоритетный проект развития Приморского края. Вестник Владивостокского государственного университета экономики и сервиса, 2017, т. 9, №1, cc. 9-17. [Latkin A.P., Verkeyenko V.V., Beloglazova V.A. Turistskorekreatsionnyy klaster "Primorskoye koltso"-prioritetnyy proyekt razvitiya Primorskogo 
kraya [Tourist and recreational cluster is a priority development project for Primorsky Region]. Vestnik Vladivostokskogo gosudarstvennogo universiteta ekonomiki i servisa, 2017, vol. 9, no. 1, pp. 9-17.]

8. Николаевская Ю.В. Состояние инфраструктуры туризма в Приморском крае. Известия Дальневосточного федерального университета. Экономика и управление, 2009, №4, cc. 21-33. [Nikolayevskaya YU. V. Sostoyaniye infrastruktury turizma v Primorskom kraye. Izvestiya Dalnevostochnogo federalnogo universiteta [The current status of the tourism infrastructure in Primorsky Krai]. Ekonomika i upravleniye, 2009, no. 4, pp. 21-33.]

9. Дмитриенко О.С. Анализ состояния туризма в Приморском крае. Сильные и слабые стороны отрасли. Территория новых возможностей. Вестник Владивостокского государственного университета экономики и сервиса, 2015, №2, сс. 166-177. [Dmitriyenko O.S. Analiz sostoyaniya turizma v Primorskom kraye. Silnyye i slabyye storony otrasli [Analysis of the state of tourism in Primorsky Krai. Strengths and weaknesses of the industry]. Territoriya novykh vozmozhnostey. Vestnik Vladivostokskogo gosudarstvennogo universiteta ekonomiki i servisa, 2015, no. 2, pp. 166-177.]

10. Департамент туризма Приморского края. Отчет о ходе реализации и оценке еффективности государственной программы Приморского края «Развитие туризма в Приморском крае на 2013-2021 годы» за 2018 год., Владивосток, 2018. [Departament turizma Primorskogo kraya. Ochet o khode realizatsii i otsenke yeffektivnosti gosudarstvennoy programmy Primorskogo kraya "Razvitiye turizma v Primorskom kraye" na 2013-2021 gody» za 2018 god [Report about the implementation and assessment of the effectiveness of the state program of the Primorsky Region "Tourism Development in the Primorsky Region 2013-2021" for 2018, Vladivostok, 2018.]

11. Пахомова А.А., Наместникова Л.С. Проблемы развития и направления поддержки предпринимательских структур Дальневосточного федерального округа. Вестник Адыгейского государственного университета. Серия 5: Экономика, 2018, №2, сс. 31-37. [Pakhomova A.A., Namestnikova L.S. Problemy razvitiya i napravleniya podderzhki predprinimatelskikh struktur Dalnevostochnogo federalnogo okruga [Problems of development and directions of support of the entrepreneurial structures of the Far Eastern Federal District]. Vestnik Adygeyskogo gosudarstvennogo universiteta. Seriya 5: Ekonomika, 2018, no. 2, pp. 31-37.]

12. Титова Н.Ю., Сяоюй Г. Управленческий учет как инструмент повышения конкурентоспособности туристских агентств. Азимут научных исследований: экономика и управление, 2019, т. 8, №3 (28), сc. 368-371. [Titova N.Yu., Syaoyuy G. Upravlencheskiy uchet kak instrument povysheniya konkurentosposobnosti turistskikh agentstv [Management accounting as a tool to strengthen the competitiveness of travel agencies]. Azimut nauchnykh issledovaniy: ekonomika i upravleniye, 2019, vol. 8, no. 3 (28), pp. 368-371].

13. Gulati R., Singh H. The architecture of cooperation: Managing coordination costs and appropriation concerns in strategic alliances. Administrative science quarterly, 1998, vol. 43, no. 4, pp. 781-814.

14.Zach F., Racherla P. Assessing the value of collaborations in tourism networks: A case study of Elkhart County, Indiana. Journal of Travel \& Tourism Marketing, 2011, vol. 28, no. 1 , pp. $97-110$.

15. Woodside A. G., Dubelaar C. A general theory of tourism consumption systems: a conceptual framework and an experimental exploration. Journal of Travel Research, 2002, vol. 41, no. 2, pp. 120-132.

16. Wang Y., Krakover S. Destination marketing: competition, cooperation or coopetition? International Journal of Contemporary Hospitality Management, 2008, vol. 20, no. 2, pp. $126-141$.

17. Damayanti M., Scott N., Ruhanen L. A review of the concept of coopetition: application in tourism. Christchurch, N.Z.: Lincoln University, 2013, pp. 135-145. 
18. Gomes-Casseres, B. The alliance revolution: The new shape of business rivalry. Harvard University Press, 1996. 71 p.

19. Luo Y.A coopetition perspective of global competition. Journal of World Business, 2007, vol. 42, no. 2, pp. 129-144.

20. Bengtsson M., Kock S. "Coopetition" in business Networks - to cooperate and compete simultaneously. Industrial marketing management, 2000, vol. 29, no. 5, pp. 411-426.

21. Brandenburger A., Nalebuff B. Coopetition. New York: Doubleday, 1996. 34 p.

22. Denicolai S., Cioccarelli G., Zucchella A. Resource-based local development and networked core-competencies for tourism excellence. Tourism management, 2010, vol. 31, no. 2, pp. 260-266.

23. Thomas R., Shaw G., Page S. J. Understanding small firms in tourism: a perspective on research trends and challenges. Tourism Management, 2011, vol. 32, no. 5, pp. 963-976.

24. Shane S., Venkataraman S. The promise of entrepreneurship as a field of research. Academy of management review, 2000, vol. 25, no. 1, pp. 217-226.

25. McGrath R.M., MacMillan I. The Entrepreneurial Mindset. Harvard Business School Press: Cambridge, MA, 2000.

26. Burgelman R.A., Hitt M.A. Entrepreneurial actions, innovation, and appropriability. Strategic Entrepreneurship Journal, 2007, vol. 1, pp. 349-352.

27. Ireland R.D., Hitt M.A., Sirmon D.G. A model of strategic entrepreneurship: The construct and its dimensions. Journal of management, 2003, vol. 29, no. 6, pp. 963-989.

28. Kyrgidou L.P., Petridou E. The effect of competence exploration and competence exploitation on strategic entrepreneurship. Technology analysis \& strategic management, 2011, vol. 23, no. 6, pp. 697-713.

29. Barney, J.B. Firm resources and sustained competitive advantage. Journal of Management, 1991, vol. 17, no. 1, pp. 99-120.

30. Hitt M.A., Ireland R.D., Camp S.M., Sexton D.L. Strategic entrepreneurship: Entrepreneurial strategies for wealth creation. Strategic management journal, 2001, vol. 22, pp. 479-491.

31. Burgelman R.A. Corporate entrepreneurship and strategic management: Insights from a process study. Management Science, 1983, vol.29, no.12, pp. 1349-1364.

32. Venkataraman S., Sarasvathy S. Strategy and entrepreneurship: Outlines of an untold story. Oxford: Blackwell, 2001, pp. 650-668.

33. Ketchen Jr D.J., Ireland R.D., Snow C.C. Strategic entrepreneurship, collaborative innovation, and wealth creation. Strategic entrepreneurship journal, 2007, vol. 1, pp. 371-385.

34. Kyrgidou L.P., Hughes M. Strategic entrepreneurship: origins, core elements and research directions. European business review, 2010, vol. 22, no. 1, pp. 43-63.

35. Klein P.G., Barney J.B., Foss N.J. Strategic entrepreneurship, 2012. Available at SSRN: http://dx.doi.org/10.2139/ssrn.2137050.

36. Kroeger J.W. Firm performance as a function of entrepreneurial orientation and strategic planning processes. Ph.D Diss. (Cleveland State University), 2007.

37. Wiklund J., Shepherd D. Knowledge-based resources, entrepreneurial orientation, and the performance of small and medium-sized businesses. Strategic management journal, 2003, vol. 24, no. 13, pp. 1307-1314.

38. Knight G.A. Cross-cultural reliability and validity of a scale to measure firm entrepreneurial orientation. Journal of business venturing, 1997, vol. 12, no. 3, pp. 213-225.

39. Ellis R.J., Taylor N.T. A typography for corporate entrepreneurship. Proceedings of the International Council for Small Business, 1988, pp. 92-96.

40. Shirokova G., Vega G., Sokolova L. Performance of Russian SMEs: Exploration, exploitation and strategic entrepreneurship. Critical perspectives on international business, 2013, vol. 9, no.1/2, pp. 173-203.

41. Ritala P. Coopetition strategy-when is it successful? Empirical evidence on innovation and market performance. British Journal of Management, 2012, vol. 23, no. 3, pp. 307-324. 
42. Galkina T., Lundgren-Henriksson E. L. Coopetition as an entrepreneurial process: interplay of causation and effectuation. Industrial Marketing Management, 2017, vol. 67, pp. $158-173$.

43. Roig-Tierno N., Kraus S., Cruz S. The relation between coopetition and innovation/entrepreneurship. Review of Managerial Science, 2018, vol. 12, pp. 379-383.

44. Ritala P., Hurmelinna-Laukkanen P. Incremental and radical innovation in coopetitionThe role of absorptive capacity and appropriability. Journal of Product Innovation Management, 2013, vol. 30, no. 1, pp. 154-169.

45. Crick J.M. Moderators affecting the relationship between coopetition and company performance. Journal of Business \& Industrial Marketing, 2018, vol. 34, no. 2, pp. 518-531.

46. Koza M.P., Lewin A.Y. The co-evolution of strategic alliances. Organization science, 1998, vol. 9, no. 3, pp. 255-264.

\section{About authors / Сведения об авторах}

Хасан Ага Муханад, кандидат экономических наук, Школа экономики и менеджмента, Дальневосточный федеральный университет. 690022 Россия, г. Владивосток, о-в Русский, кампус ДВФУ, корпус G. E-mail: agha.muhanad@ gmail.com

Hasan Agha Muhanad, Ph.D. Candidate in Economics, School of Economics and Management, Far Eastern Federal University. Building G, FEFU campus, Russky Island, Vladivostok, Russia 690922.

E-mail: agha.muhanad@gmail.com

Гаффорова Елена Борисовна, доктор экономических наук, доцент, профессор кафедры менеджмента, директор Школы экономики и менеджмента, исследователь научноисследовательской лаборатории «Лаборатория исследования предпринимательства», Дальневосточный федеральный университет. 690920 Россия, г. Владивосток, о-в Русский, кампус ДВФУ, корпус G, каб. G609. E-mail: gafforova.eb@dvfu.ru

Elena B. Gafforova, Doctor of Economic Sciences, Associate Professor, Professor, the Department of Management, Director, School of Economics and Management, Researcher, the Research Laboratory "Laboratory of Entrepreneurship Research", Far Eastern Federal University. Office G609, Building G, FEFU campus, Russky Island, Vladivostok, Russia 690920. E-mail: gafforova.eb@dvfu.ru 